\title{
Does FDI Caused Profit Repatriation: Exploring the Moderating Role of Governance Institutions
}

\author{
Ghalib Bin Faheem (Corresponding author) \\ Research Scholar, Karachi University Business School, University of Karachi, Pakistan \\ E-mail: ghalib_faheem@yahoo.com
}

Dr. Danish Ahmed Siddiqui

Associate Professor, Karachi University Business School, University of Karachi, Pakistan

E-mail: daanish79@ hotmail.com

Received: March 19, 2020 Accepted: April 11, 2020 Published: April 18, 2020

doi:10.5296/ber.v10i2.16704ＵRL: https://doi.org/10.5296/ber.v10i2.16704

\begin{abstract}
This paper investigates the impact of foreign direct investment, institutional quality on profit repatriation and net primary income taken as a proxy of profit repatriation. Inflation and GDP per capital were taken as controls. Data sample of 54 countries (developing) has been used for the first model of this research. And data sample of 100 countries (developed and developing both) has been used for the second model. The sample period is from 2008-2017. Finding of this study indicate that institutions quality is negatively impacting profit repatriation and net primary income. It also reveals foreign direct investment is negatively affecting profit repatriation but positively impacting net primary income. Results reveal that investors are unwilling to invest in countries where institutions encourage corruption, because these factors increase the cost of doing business. Developing countries have weaker institutions than developed countries and so, investors will be taking their profit back and not willing to re-invest in that particular country.
\end{abstract}

Keywords: Profit Repatriation, Foreign Direct Investment, Institutional Index, Accountability, Profitability, Corruption

\section{Background to the Study}

The importance of FDI to developing countries is noted in UNCTAD (2002, page 5) which states: 
"Foreign direct investment contributes toward financing sustained economic growth over the long term. It is especially important for its potential to transfer knowledge and technology, create jobs, boost overall productivity, enhance competitiveness and entrepreneurship, and ultimately eradicate poverty through economic growth and development."

Foreign Direct Investment boosts the economy by creating employment opportunities, transfers skills and technologies, increases in productivity, and continuous long term development in the developing countries. It also serves as a major source of the external capital inflow for the host countries. In recent years, there is a move by many developing and emerging economies to seek more actively to attract foreign direct investment. For attracting more FDI into the country, better institutional quality plays a very important role (Du, Lu, \& Tao, 2008; Dang, 2013). It is well known that foreign investors pay a great deal of attention to the institutional framework of the countries in which they undertake an investment (OECD 2012). Firms and investors of foreign countries are interested to invest in other countries due to the availability of cheap raw materials and cheap labor costs to maximize their profit. (Hussain and kimuli, 2012).

Moreover, institutional quality has a positive and significant impact on FDI in developed countries. Good institutions affect economic activities through different channels such as by reducing the transaction, manufacturing and production costs. Moreover, good quality institutions help reduce the cost of doing business, which increases profitability. However markets with poor institutions take up more time and resources for monitoring. When property rights are poorly protected and contract enforcement is difficult, the risk premium is high and economic activity is slower. International investors hesitate to invest in such a risky and conducive environment. By contrast, a risk-free environment is a good location for the source country and good institutions also lead to better FDI utilization.)

While, on the other hand Profit repatriation is the ability of a firm to send foreign - earned profits or financial assets back to the firm's home country in hard currency such as US\$, Euro, and Pound, after meeting host nation's tax obligations. Foreign investors largely depends on the institutions of a country, if institutions of a country in which they are investing are really strong in terms of Voice and Accountability, Political stability, Control of corruption, Government effectiveness, Regulatory Quality and Rule of Law, so instead of doing profit repatriation they also had an option of re-investing in that country. And if institutions are weak of a particular country, it makes foreign investor to take the profit to their own country, which is not a good thing for a host nation.

The repatriation of profits refers to the return of the money earned in the host country to the country where the business is owned. If the host nation has offered tax incentives to the foreign firms it results in greater amount of profit after tax reduction. The amount of future investment the foreign firm wishes to make in the host nation; if it wants to make a future investment it is likely to use their profit for this to avoid transaction and currency exchange costs. If the country of origin has high taxes, it is more likely that profit will sent back to home or for the investment in other countries. Host countries want as much of the profit as this helps their economy. Foreign direct investment is much larger in Europe then North 
America and Asia. Foreign direct investment inflows are coming more in countries with strong institutions and very less in countries with low value institutions. And this is mostly because of strong institutions, business friendly environment \& policies and tax incentive policies.

\section{Problem Statement}

Problems in maintaining the flow of capital is not simple. It is a perplex process for developing countries with transition economy. Corruption, geopolitical risk and insufficient modern infrastructure are not only the reasons for the failure to attract foreign direct investment in developing countries. The primary causes to increase the flow of foreign direct investment are lack of commitment to reforms, functional private sector absence, lack of research and development, low level of innovation and hackneyed education system. Some of the major shortcomings of Asian developing countries are lack of skilled labor, counterproductive taxation, poor infrastructure and strict government rules and regulations. While strategic geographical location, economic stability and reliability, natural resources, market size, availability of skilled labor, government policies and reforms, and other lucrative opportunities for foreign investors could be major determinants of foreign direct investment flow to a developing countries. Sanderatne (2013) studied the problems faced by Sri Lanka in attracting foreign direct investment by using deductive method. His result reveals that solid presence of macroeconomic fundamentals, well established economic policies, commitment to encourage and protect investors rights and less government control over businesses is crucial to attract greater amount of foreign direct investment flow in a country. The research will help to understand the relationship between profit repatriation and foreign direct investment in developing as well as developed countries with the importance of institutions. Many previous researches has been done on the importance of foreign direct investment but this research will show the importance of institutions as well as profit repatriation as there are no many researches between foreign direct investment and profit repatriation.

\section{Gap Analysis}

Lehman (2002) found that structural change in country's external accounts takes place due to foreign direct investment inflows. Trade openness and host country risks are found to increase profitability of FDI and earning repatriations However, this research by only focusing on two countries, and the time span was only of 5 years that is 1996-2000. The countries were Brazil and Argentina. FDI is mainly responsible for huge current account deficit in these countries according to this research due to huge income repatriations. Peres, M., Ameer, W., \& Xu, H. (2018) explains the impact on Foreign Direct Investment inflows in developed and developing countries using corruption and the rule of law as measures of institutional quality; they have bridge this by categorizing the countries as developed or developing to more accurately measure the importance of institutions in attracting FDI inflows. The results for developing countries regarding the impact of governance on FDI are robust. On the other hand the results for developed countries the governance had a significant effect on FDI inflows. While, Peres, M., Ameer, W., \& Xu, H. (2018) has selected the data set of 41 developed and 69 developing, however, the period covered was from 2002 to 2012. 
Moreover, Profit repatriation was not included in that research. As this better capture the downsides of FDI on balance of payment. Harms and Ursprung (2002) investigated whether there is a significant effect of a country's political system on the volume of FDI inflows. They find that foreign investors invest in those countries who have strong democratic structures, while other countries experience policy reversal and attract less FDI. They also covered the period from 1989 to 1997 . Moreover, they lacks the comparison with developed countries

All of the above researches have mainly focuses on foreign direct investment. In this research the main focus is on profit repatriation and we are using institutional index as a moderating variable. We have selected the data set of 100 countries where 54 is developing and 46 are developed nations with a time span of 2008 to 2017 by using GMM method (Generalized method of moment). There are very few studies which have focused on profit repatriation and that also as an independent variable. We have also divided this studies into 4 regions that are American, European, Asian and African regions to know the effect of foreign direct investment and institutional index on profit repatriation in those particular regions by showing through scatter graph.

\section{Research Objectives}

The purpose of this research is to know if strong institutions in host nation causes the flow of profit repatriation, or this is the case of weak institutions. In strong institutions, profit repatriation will be low as it will provide foreign companies to invest that profit into a host nation. And if the institutions are weak of the host nation then the ratio will be high as there will be no chances of investing in a host nation by a foreign nation. Hence, we aim to empirically examine the linkages between Profit Repatriation, Foreign Direct Investment and Institutions, by using the dynamic panel estimation model of Arellano and Bover (1995) and Blundell and Bond (1998).

For our first model, we use an extensive data set covering 54 countries over the period of 2008-2017 to study the link between institutional quality, Foreign Direct Investment and profit repatriation. The objective of this research is to identify that if the institutions are strong of the host nation, then the ratio of profit repatriation will be low. And if the institutions are weak of the host nation, then the ratio of profit repatriation will be high.

We will see the impact of foreign direct investment on profit repatriation through three situations: First we check the impact of foreign direct investment without governance factors (institutions), then we check it with governance factors (institutions) and then we will check it with governance factors and interaction effect of governance factors with foreign direct investment.

Then for our second model we use an extensive data set covering 100 countries (developed and developing) over the period of 2008-2017. This model analyzes the link between institutional quality, Foreign Direct Investment and Net Primary Income (as a proxy of profit repatriation) which has been overlooked by many of the existing studies.

We will see the impact of foreign direct investment on Net Primary Income through three situations: First we check the impact of foreign direct investment without governance factors 
(institutions), then we check it with governance factors (institutions) and then we will check it with governance factors and interaction effect of governance factors with foreign direct investment. The presence of interaction effects in any kind of survey research is important because it tells researchers how two or more independent variables work together to impact the dependent variable. The main source of data is the World Bank. We obtained data of Inflation, GDP per Capital, FDI (in Dollars), Net Primary Income (in Dollars) and Profit Repatriation (in Dollars) from World Bank. We have obtained data of institutional variables i.e. control of corruption, voice and accountability, government effectiveness, political stability, rule and law, and regulatory quality from World Bank as well.

We will also see the impact of foreign direct investment and institutional quality on profit repatriation region wise. We will divide the countries into 4 regions i.e. Asian region, African region, American Region and European region. It will explain how particular region countries affecting profit repatriation with their foreign direct investment inflows and governance factors which include (control of corruption, voice and accountability, government effectiveness, political stability, rule and law, and regulatory quality) in their region. Another impact which we will focused in this research will be of countries with low value institutions and high value institutions on profit repatriation. It will explain how countries with weaker institutions increases profit repatriation as compare to countries with high value institutions. Weaker institutions can't attract the foreign investors to invest their profit within the host nation. As foreign firms likely to use their profit for transactions and currency cost. The tax incentive system is most beneficial for the foreign firm in the host nation which is least likely to be provided by developing nations Distracting factors can be cost of borrowing, poor monetary policies, poor law system and no political stability etc. And countries with high value institutions attract the foreign investors to invest their profit with in the host nation. Attracting factors can be friendly monetary policies, strong law system, friendly tax policies etc.

\section{Significance}

There are many researches on foreign direct investment and institutions but profit repatriation is not highlighted by current or past researchers as it should be. This research will help industry to understand the impact of foreign direct investment and institutions on profit repatriation. This research will also provide the details about the comparison of profit repatriation in low value institutions countries with high value institutions countries. It will also make them understand why repatriation of profit is higher in developing countries (low value institutions) as compare to developed countries (high value institutions). It will also explain why investors are willing to re-invest their profit in the country which have strong institutions and why investors are afraid of investing in the host nation where institutions are weak and taking their profit back to home.

\section{Literature Reviews}

Buchanan (2012) examines the impact of institutional quality on foreign direct investment levels and volatility. They use panel data for 164 countries from 1996 to 2006. Findings of the study explain that good institutional quality matters to FDI. Results suggest that if there 
are institutional determinants of FDI volatility and if such thing is offered with countries which have lower growth then the policy of attracting foreign direct investment into such lower growth countries would be ineffective.

Dang (2013) explains how foreign direct investment promotes institutional quality. He has focused on Vietnam. He used a data set from a provincial competitiveness survey and the rising foreign direct investment (FDI). Findings of the study shows the variations in economic institutions across the provinces of Vietnam are associated with the flow of foreign investment. It also shows that foreign direct investment has greater short-term impacts on institutional quality in the northern provinces.

Mengistu 2011 examines the effects of the six components of good governance on foreign direct investment (FDI). He used a data set of 15 Asian economies for the period of 1996-2007, used a fixed effect model for a panel data. A result reveals that of the six components of good governance, political stability and absence of violence, government effectiveness, rule of law and control of corruption are the key determinants of foreign direct investment inflows as they provide consistent results in different models. Results also suggest that there is no significant evidence between foreign direct investment inflows and voice and accountability and regulatory quality.

Miheala Peres, Waqar Ameer \& Helian Xu 2018, examines the impact of institutional quality (governance index) on foreign direct investment. They have categorized their data into developing and developed countries. They provided evidence that institutional quality positively and significantly impacts foreign direct investment in developed countries. Results for developing countries reveals that the institutional quality impact is insignificant because of the weak structure of institutions. A result also supports the significance of governance indicators in attracting foreign direct investment inflows.

Lehmann (2002) examines the determinants of foreign direct investment profitability in 43 countries (developing). After the control of leverage in finance and the effect of minimization of tax income transfers, risk and market openness of host country found to raise affiliate returns on equity and return on sales. During the financial crisis of 1990's income repatriations have shown to be pro-cyclical, though the effect of host country recessions is mitigated through re-direction of sales and continuous spending on fixed assets.

Trojette (2016) examines whether the effect of foreign direct investment on economic growth is dependent upon the institutional level. Focus of this study is on the 5 regions (SSA, MENA, Europe, Asia and America). They are focusing on the institutional level for these five regions. He used a GMM model for a unique data set covering a period from 1984-2013. Findings of the study reveal that the factors of the institutions matter for all group except for the America Group. Factors of institutions reveal that above the threshold of government stability and the respect of law and order foreign direct investment enhances GDP growth. Results reveal the role of institutional development in moderating the ambivalent impacts of foreign direct investment on GDP growth.

Cristina Jude, Gregory Levieuge (2015) examines the effect of foreign direct investment on 
economic growth conditional on the institutional quality of host countries. They used a data set of 94 developing countries over the period of 1984-2009. They used Panel Smooth Transition Regression (PSTR) that allows identifying both the heterogeneity and the threshold of institutional quality that influence the foreign direct investment growth effect. Results reveal that the improvement of the institutional framework should precede foreign direct investment attraction policies in order to benefit FDI-led growth.

Sabir (2019) this paper examines the impact of institutional quality on foreign direct investment inflows using panel data for income countries (low, lower-middle, upper-middle, high). Using a sample period from 1996-2016. Using the system Generalized method of moments (GMM). Results of this study reveal that institutional quality has a positive impact on foreign direct investment in all countries. The magnitude of governance factors are greater in developed countries than in developing countries and institutional quality is a more important determinant of FDI in developed countries than in developing countries

\section{Trend Analysis}

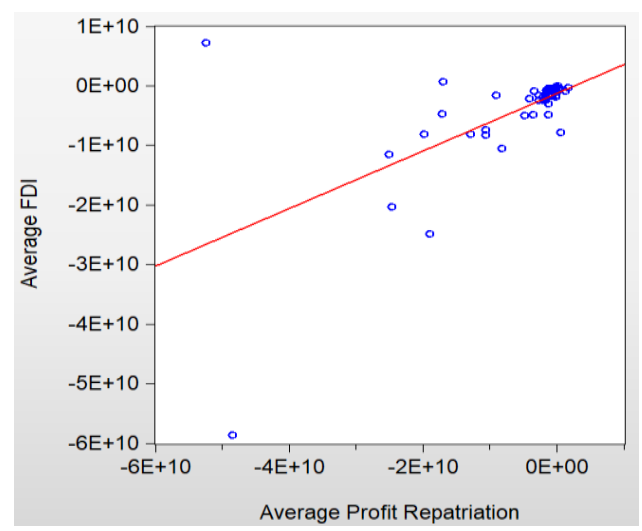

Figure 1. Scatter Plot of FDI and Profit Repatriation for Low Value Institutions

This is a scatter plot of foreign direct investment and profit repatriation of low value institutions. We have taken average of foreign direct investment on Y-axis and average of profit repatriation on X-axis for the timeline of 2008 to 2017 of 54 countries with low value institutions. The outliners in this graph are Russia $(-5.24 \mathrm{e}+10,7.26 \mathrm{e}+09)$, Brazil $(-4.85 \mathrm{e}+10$, $-5.85 e+10)$ because they are far away from the regression line. 


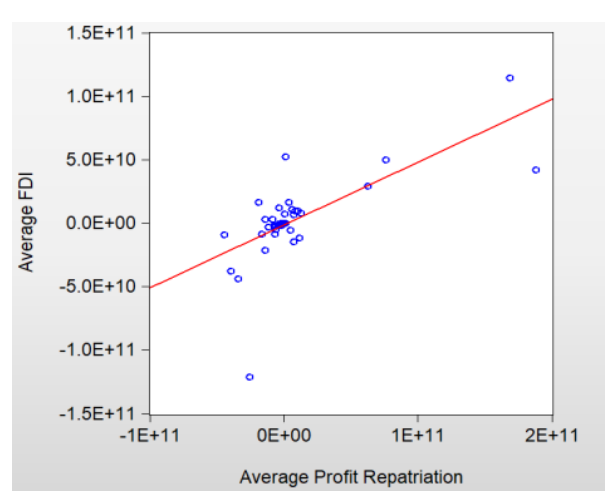

Figure 2. Scatter Plot of FDI and Profit Repatriation for High Value Institutions

This included 46 countries with high value institutions. The outliners in this graph is China $(-2.56 e+10,-1.21 e+11)$, as it is far away from the regression line.

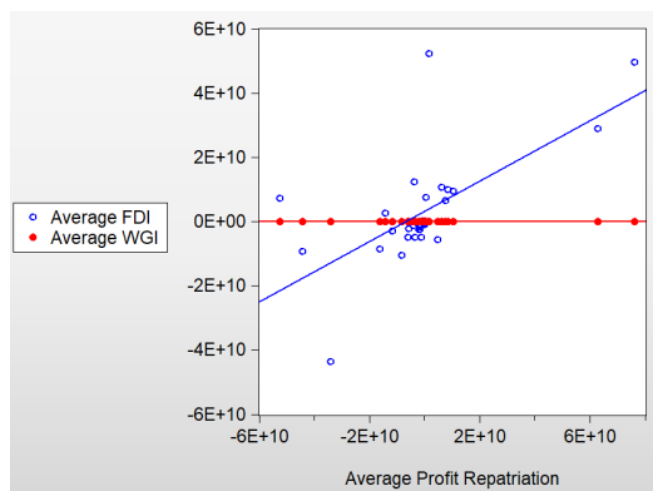

Figure 3. Scatter Plot of European Region

This is a scatter graph of foreign direct investment, institutions and profit repatriation of a European Region. This included 32 European countries. The outliners in this graph are United Kingdom $(-3.40 \mathrm{e}+10,-4.36 \mathrm{e}+10)$, Netherlands $(1.54 \mathrm{e}+09,5.24 \mathrm{e}+10)$ as they are distant from the regression line.

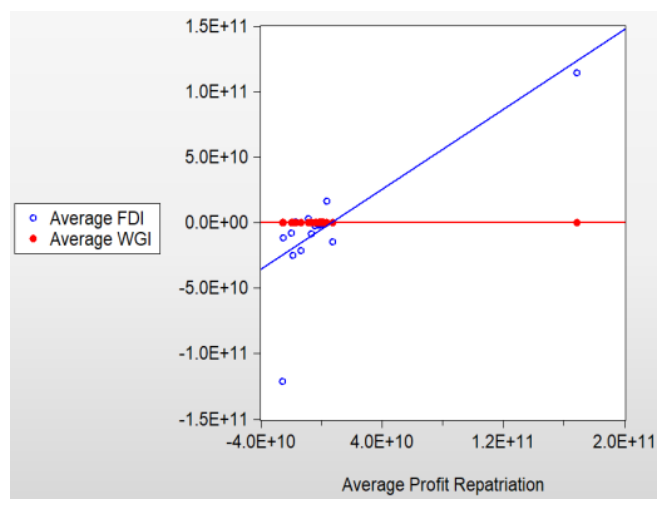

Figure 4. Scatter Plot of Asian Region 


\section{Macrothink}

Business and Economic Research

ISSN 2162-4860

2020, Vol. 10, No. 2

This included 23 Asian countries. The outliner in this graph is China $(-2.56 e+10,-1.21 \mathrm{e}+11)$ as it is far away from the regression line.

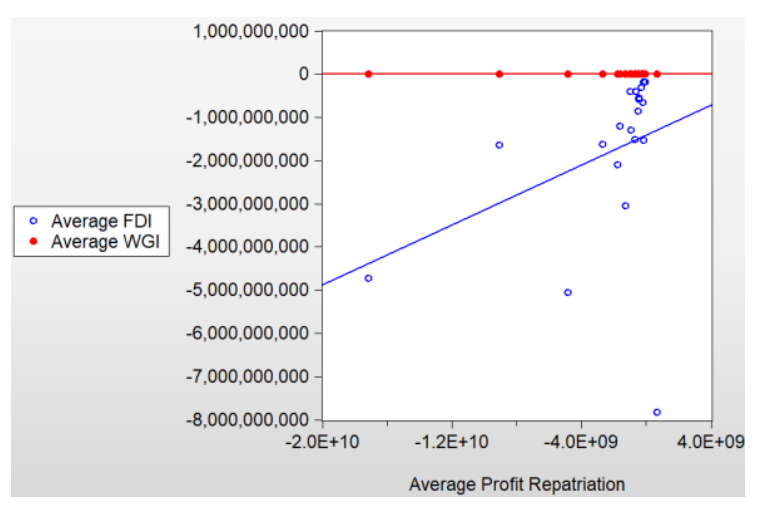

Figure 5. Scatter Plot of African Region

This is a scatter graph of foreign direct investment, institutions and profit repatriation of an African Region. 20 African countries are included. The outliners in this graph are Egypt $(-4.83 e+09,-5.05 e+09)$, Ghana $(-1.27 e+09,-3.04 e+09)$, Mauritius $(6.42 e+08,-7.83 e+09)$, Seychelles $(-7.72 \mathrm{e}+09,-1.86+08)$ and Burkina Faso $(-1.78 \mathrm{e}+08,-1.77 \mathrm{e}+08)$ as they are far away from the regression line.

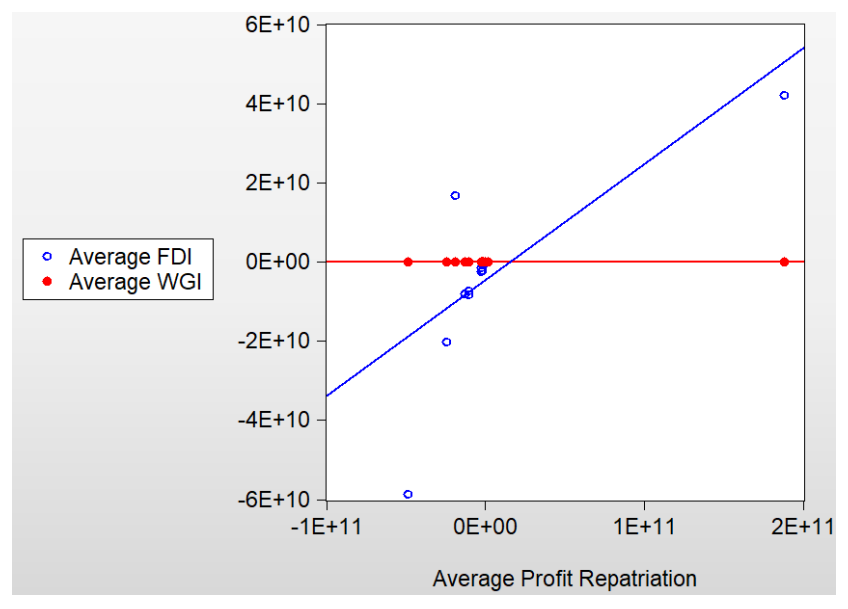

Figure 6. Scatter Plot of American Region

15 American countries are included from the American region for this research. The outliners in this graph is Brazil $(-4.85 e+10,-5.85 e+10)$ as it is far away from the regression line.

\section{Methodology}

\subsection{Research Design}

Causal research design is used in this study in order to find out the influence of inflation rate, GDP per Capital, foreign direct investment and governance factors (institutions index) on profit repatriation and net primary income. In this research we are analysing that how 
significantly or insignificantly profit repatriation and net primary income gets affected due to inflation rate, GDP per Capital, foreign direct investment and governance factors (institutions index)

\subsection{Data Sources and Sample Size}

Table 1

\begin{tabular}{|l|l|c|}
\hline \multicolumn{1}{|c|}{ Variable name } & \multicolumn{1}{|c|}{ Description } & Source \\
\hline Profit Repatriation & $\begin{array}{l}\text { Profit earned in a foreign country that one wishes to bring into the } \\
\text { borders of one's own country. }\end{array}$ & World Bank \\
\hline Net Primary Income & $\begin{array}{l}\text { Net primary income refers to investment income (receipts and } \\
\text { payments on direct investment, portfolio investment, other } \\
\text { investments, and receipts on reserve assets). }\end{array}$ & World Bank \\
\hline Foreign direct Investment & $\begin{array}{l}\text { Foreign direct investment (FDI) is an investment in a business by an } \\
\text { investor from another country for which the foreign investor has } \\
\text { control over the company purchased. }\end{array}$ & World Bank \\
\hline Inflation & $\begin{array}{l}\text { Inflation is an economic term that refers to an environment of } \\
\text { generally rising prices of goods and services within a particular } \\
\text { economy. }\end{array}$ & World Bank \\
\hline GDP Per Capital & $\begin{array}{l}\text { GDP per capita is a measure of a country's economic output that } \\
\text { accounts for its number of people. It divides the country's gross } \\
\text { domestic product by its total population. }\end{array}$ & World Bank \\
\hline Institutional Index & $\begin{array}{l}\text { It aims to provide, year on year, a precise image of the situation of } \\
\text { world governance and of its evolution. }\end{array}$ & World Bank \\
\hline
\end{tabular}

Secondary data is a data that has earlier been collected and can be retrieved by the researcher. In this research we will find out the connection between inflation rate, GDP per Capital, foreign direct investment, governance factors (institutions index), profit repatriation and net primary income. Due to this, historical data of inflation rate, GDP per Capital, foreign direct investment, governance factors (institutions index), profit repatriation and net primary income were used to analyze the result. The data for the research was gathered from a single source that is World Bank. In this paper we have acquired 10 years of data from the period 2008 to 2017 and we have taken 54 countries (developing countries) for our first model in which profit repatriation is our dependent variable

These countries include Albania, Argentina, Armenia, Azerbaijan, Bangladesh, Burkina Faso, Bosnia and Herzegovina, Belarus, Botswana, Bulgaria, Bolivia, Brazil, Cameroon, Colombia, Costa Rica, Cote d'Ivoire, Ecuador, Dominican Republic, Ethiopia, Fiji, Ghana, Egypt, Georgia, Indonesia, India, Jamaica, Jordan, Kazakhstan, Kenya, Cambodia, Sri Lanka, Morocco, Mexico, Mauritius, Nigeria, Nepal, Pakistan, Peru, Philippines, Paraguay, Romania, Russia, Sudan, Senegal, Serbia, Thailand, Tajikistan, Tunisia, Turkey, Tanzania, Uganda, Ukraine, South Africa, Zambia.

Then we have acquired 10 years' data from the period 2008-2017 for which we have taken 100 countries (developed and developing countries) for our second model in which net primary income is our dependent variable.

The 100 countries are Australia ,Austria, Belgium, Bahrain, Canada, Switzerland, China, Czech Republic, Germany, Denmark, Spain, Finland, France, United Kingdom, Greece, Hong Kong, Croatia, Hungary, Ireland, Iceland, Italy, Japan, Korea Republic, Kuwait, Maldives, 
Malaysia, Netherlands, Norway, New Zealand, Oman, Poland, Saudi Arabia, Singapore, Sweden, United States, Albania, Argentina, Armenia, Azerbaijan, Bangladesh, Burkina Faso, Bosnia and Herzegovina, Belarus, Botswana, Bulgaria, Bolivia, Brazil, Cameroon, Colombia, Costa Rica, Cote d'Ivoire, Ecuador, Dominican Republic, Ethiopia, Fiji, Ghana, Egypt, Georgia, Indonesia, India, Jamaica, Jordan, Kazakhstan, Kenya, Cambodia, Sri Lanka, Morocco, Mexico, Mauritius, Nigeria, Nepal, Pakistan, Peru, Philippines, Paraguay, Romania, Russia, Sudan, Senegal, Serbia, Thailand, Tajikistan, Tunisia, Turkey, Tanzania, Uganda, Ukraine, South Africa, Zambia, Slovak Republic, Antigua and Barbuda, Bermuda, Brunei Darussalam, Cyprus, Grenada, Namibia, Portugal, Seychelles, Vietnam and Uruguay.

\subsection{Statistical Tools and Techniques}

We used GMM method dynamic panel estimation model to find out the impact of inflation rate, GDP per Capital, foreign direct investment, governance factors (institutions index) on profit repatriation and net primary income. Generalized method of moments is convenient for estimating interesting extensions of the basic unobserved effect models. Generalized method of moments is applied more often to unobserved effects models when the explanatory variables are not strictly exogenous even after controlling for an unobserved effect. Significant GMM improvements are most likely in time series or panel data applications with neglected serial correlation.

\subsection{Regression Specification}

In this study we are finding out the influence of inflation rate, GDP per Capital, foreign direct investment and governance factors (institutions index) on profit repatriation and net primary income. So the Dependent variable of our first group, is Profit Repatriation and the independent variables are inflation, GDP per Capital, Foreign Direct Investment and Governance Factors (Institutional Index). Governance factors include Voice and Accountability, Control of Corruption, Government Effectiveness, Residual Quality, Rule of law and Political stability. In the second group, the dependent variable of our second model is Net Primary Income while other remained the same.

The main objective of all foreign investments is to make profit and repatriate those profits to the home state. When a foreign firm invests in a host country and then reinvest the profits there, a multiplier effect might arise. However, when profits are exported or repatriated instead of reinvested, repatriation might start five years after initial investment. The country loses capital for accumulation and investment, which if not compensated for by new foreign direct investment will result in a negative investment multiplier.

The rate of inflation in a country can have a major impact on the value of the country's currency and the rates of foreign exchange it has with the currencies of other nations. Inflation is more likely to have a negative effect, rather than a significant positive effect, on a currency's value and foreign exchange rate. Investor first consideration in regard to currency, before whatever profit they may realize, is the safety of holding cash assets in the currency. If a country is perceived as politically or economically unstable, investors tend to shy from the currency and are reluctant to hold it for significant periods or in large amounts. 


\section{I Macrothink}

Business and Economic Research

ISSN 2162-4860

2020, Vol. 10, No. 2

Similarly, if the institutions are weak of a host nation, investor will be afraid of investing in that country as they thinks there money will be not secure, because of the political instability and high cost of borrowing. He will not think of re-investing in that particular nation as their own investment is not secure so they have to repatriate their whole investment to their home country.

\section{Results}

\subsection{Descriptive Statistics}

Table 2

\begin{tabular}{|l|l|l|l|l|l|l|l|l|l|l|}
\hline & $\begin{array}{l}\text { PROFIT_ } \\
\text { REPATRI } \\
\text { ATION }\end{array}$ & INFLATION & $\begin{array}{l}\text { GDP_PER_ } \\
\text { CAPITAL }\end{array}$ & FDI_\$ & $\begin{array}{l}\text { RULE_OF } \\
\text { _LAW }\end{array}$ & RQ & PS & $\begin{array}{c}\text { V_AND_ } \\
\text { A }\end{array}$ & COC & GOVT_E \\
\hline Mean & $-1.79 \mathrm{E}+08$ & 4.986936 & 1.841320 & $-1.32 \mathrm{E}+09$ & 0.249201 & 0.353634 & 0.010369 & 0.146279 & 0.210904 & 0.320778 \\
\hline Median & $-1.11 \mathrm{E}+09$ & 3.076496 & 1.987105 & $-8.93 \mathrm{E}+08$ & 0.056215 & 0.253092 & 0.066965 & 0.115582 & -0.068174 & 0.164294 \\
\hline Maximum & $2.26 \mathrm{E}+1$ & 75.27737 & 23.94065 & $1.73 \mathrm{E}+1$ & 2.100273 & 2.260543 & 1.593475 & 1.737975 & 2.446495 & 2.436975 \\
\hline Minimum & $-7.96 \mathrm{E}+1$ & -25.95842 & -14.37929 & $-2.32 \mathrm{E}+1$ & -1.423214 & -1.560386 & -2.810035 & -1.907197 & -1.544762 & -1.532044 \\
\hline Std. Dev. & $3.09 \mathrm{E}+1$ & 7.582057 & 3.436544 & $2.98 \mathrm{E}+1$ & 0.940136 & 0.857260 & 0.912882 & 0.910492 & 1.022266 & 0.902629 \\
\hline Skewness & 4.204130 & 2.507429 & -0.387234 & -1.207743 & 0.427293 & 0.253311 & -0.517008 & -0.143067 & 0.614836 & 0.395375 \\
\hline Kurtosis & 27.39619 & 19.27431 & 6.384580 & 24.44861 & 2.043686 & 2.148514 & 2.675958 & 2.055923 & 2.244441 & 2.144511 \\
\hline Jarque-Bera & 27744.71 & 12083.41 & 502.2992 & 19411.56 & 68.53553 & 40.90392 & 48.92471 & 40.54806 & 86.79003 & 56.54780 \\
\hline Probability & 0.000000 & 0.000000 & 0.000000 & 0.000000 & 0.000000 & 0.000000 & 0.000000 & 0.000000 & 0.000000 & 0.000000 \\
\hline Observations & 1000 & 1000 & 1000 & 1000 & 1000 & 1000 & 1000 & 1000 & 1000 & 1000 \\
\hline
\end{tabular}

\subsection{Correlation}

Table 3

\begin{tabular}{|l|l|l|l|l|l|}
\hline & PROFIT_REPATRIATION & FDI_\$ & GDP_PER_CAPITAL & INFLATION & WGI \\
\hline PROFIT_REPATRIATION & 1.000000 & 0.511052 & -0.084788 & -0.108467 & 0.209526 \\
\hline FDI_\$ & 0.511052 & 1.000000 & -0.150784 & -0.071997 & 0.174038 \\
\hline GDP_PER_CAPITAL & -0.084788 & -0.150784 & 1.000000 & 0.145004 & -0.247112 \\
\hline INFLATION & -0.108467 & -0.071997 & 0.145004 & 1.000000 & -0.365722 \\
\hline WGI & 0.209526 & 0.174038 & -0.247112 & -0.365722 & 1.000000 \\
\hline
\end{tabular}

Table 3, show the analysis of correlation. World Governance indicators, Foreign Direct Investment, GDP per Capital and inflation are the independent variables. Profit Repatriation is a dependent variable. Profit Repatriation has a negative relation with GDP per Capital and Inflation having values of $-0.084788,-0.108467$ respectively. Profit repatriation has a moderate relationship with Foreign Direct investment and World Governance index having values of $0.511052,0.209526$ respectively. There is a high and strong positive correlation among all the WGI (world Governance indicators) because their value is greater than 0.7 , this means that there is high multicollinearity, therefore we have done the factor analysis of all he indicators of WGI.

\subsection{Regression}

Table 4

\begin{tabular}{|l|l|l|l|l|l|l|l|}
\hline Variable & \multicolumn{4}{|l|}{ Profit Repatriation } & \multicolumn{2}{l|}{ Net Primary Income } \\
\hline & & Model 1 & Model 2 & Model 3 & Model 1 & Model 2 & Model 3 \\
\hline
\end{tabular}


Business and Economic Research ISSN 2162-4860 2020, Vol. 10, No. 2

\begin{tabular}{|c|c|c|c|c|c|c|c|}
\hline \multirow{3}{*}{$\begin{array}{l}\text { PROFIT_REP(- } \\
\text { 1) }\end{array}$} & Coefficient & 0.375556 & 0.360994 & -0.087682 & 0.19178 & 0.188474 & 0.174808 \\
\hline & $\mathrm{t}$-Statistic & 310.9384 & 149.5643 & -19.11714 & 95.03863 & 79.35265 & 28.58224 \\
\hline & Prob. & 0 & 0 & 0 & 0 & 0 & 0 \\
\hline \multirow[t]{3}{*}{ INFLATION } & Coefficient & $\begin{array}{l}1928022 \\
8\end{array}$ & 20031975 & -8723520 & $\begin{array}{l}-3185468 \\
9\end{array}$ & $\begin{array}{l}-4061856 \\
5\end{array}$ & $\begin{array}{l}-3891397 \\
9\end{array}$ \\
\hline & t-Statistic & 6.52846 & 4.9276 & -2.319645 & -2.72775 & -2.262581 & -2.29918 \\
\hline & Prob. & 0 & 0 & 0.0209 & 0.0065 & 0.0239 & 0.0218 \\
\hline \multirow[t]{3}{*}{$\begin{array}{l}\text { GDP_PER_ } \\
\text { CAPITAL }\end{array}$} & Coefficient & $2.57 \mathrm{E}+08$ & $2.39 \mathrm{E}+08$ & $2.30 \mathrm{E}+08$ & $-1.10 \mathrm{E}+08$ & $-1.10 \mathrm{E}+08$ & $\begin{array}{l}-7314363 \\
3\end{array}$ \\
\hline & $\mathrm{t}$-Statistic & 39.0527 & 20.36336 & 12.14849 & -3.535044 & -2.986527 & -3.314082 \\
\hline & Prob. & 0 & 0 & 0 & 0.0004 & 0.0029 & 0.001 \\
\hline \multirow[t]{3}{*}{ FDI_\$ } & Coefficient & -0.13228 & -0.124048 & -0.17312 & 0.075982 & 0.075886 & 0.320631 \\
\hline & $\mathrm{t}$-Statistic & -176.068 & -86.68189 & -29.34279 & 121.794 & 58.85837 & 22.04297 \\
\hline & Prob. & 0 & 0 & 0 & 0 & 0 & 0 \\
\hline \multirow[t]{3}{*}{$\mathrm{COC}$} & Coefficient & & $9.92 \mathrm{E}+08$ & $\begin{array}{l}-1.76 \mathrm{E}+0 \\
9\end{array}$ & & $4.55 \mathrm{E}+08$ & $7.19 \mathrm{E}+08$ \\
\hline & $\mathrm{t}$-Statistic & & 3.239612 & -3.19243 & & 0.83797 & 0.924439 \\
\hline & Prob. & & 0.0013 & 0.0015 & & 0.4023 & 0.3555 \\
\hline \multirow[t]{3}{*}{ GOVT_E } & Coefficient & & $5.91 \mathrm{E}+08$ & $1.62 \mathrm{E}+09$ & & $-1.46 \mathrm{E}+08$ & $-5.08 \mathrm{E}+08$ \\
\hline & t-Statistic & & 2.462812 & 5.115371 & & -0.388447 & -0.670842 \\
\hline & Prob. & & 0.0142 & 0 & & 0.6978 & 0.5025 \\
\hline \multirow[t]{3}{*}{ PS } & Coefficient & & $\begin{array}{l}-1.27 \mathrm{E}+0 \\
9\end{array}$ & $\begin{array}{l}-3.43 \mathrm{E}+0 \\
8\end{array}$ & & -40581110 & $-3.01 E+08$ \\
\hline & t-Statistic & & -10.12785 & -1.409697 & & -0.072035 & -0.316125 \\
\hline & Prob. & & 0 & 0.1594 & & 0.9426 & 0.752 \\
\hline \multirow[t]{3}{*}{ RQ } & Coefficient & & $2.88 \mathrm{E}+09$ & $7.91 \mathrm{E}+08$ & & $-1.05 E+09$ & $-2.63 E+08$ \\
\hline & $\mathrm{t}$-Statistic & & 9.081196 & 1.585586 & & -2.197671 & -0.739257 \\
\hline & Prob. & & 0 & 0.1136 & & 0.0283 & 0.46 \\
\hline \multirow[t]{3}{*}{$\begin{array}{l}\text { RULE_OF_LA } \\
\mathrm{W}\end{array}$} & Coefficient & & $8.09 \mathrm{E}+08$ & $\begin{array}{l}-1.37 \mathrm{E}+0 \\
9\end{array}$ & & $-1.63 \mathrm{E}+09$ & $-1.90 \mathrm{E}+09$ \\
\hline & $\mathrm{t}$-Statistic & & 2.638539 & -2.757364 & & -2.23028 & -2.73661 \\
\hline & Prob. & & 0.0086 & 0.0061 & & 0.026 & 0.0063 \\
\hline \multirow[t]{3}{*}{ V_AND_A } & Coefficient & & $1.85 \mathrm{E}+09$ & $1.12 \mathrm{E}+09$ & & $2.97 \mathrm{E}+09$ & $3.83 \mathrm{E}+09$ \\
\hline & $\mathrm{t}$-Statistic & & 5.494089 & 1.269549 & & 3.462549 & 4.836282 \\
\hline & Prob. & & 0 & 0.205 & & 0.0006 & 0 \\
\hline \multirow[t]{3}{*}{ COC*FDI_\$ } & Coefficient & & & -0.501269 & & & -0.009751 \\
\hline & $\mathrm{t}$-Statistic & & & -35.74554 & & & -0.696971 \\
\hline & Prob. & & & 0 & & & 0.486 \\
\hline \multirow{3}{*}{$\begin{array}{l}\text { GOVT_E*FDI_ } \\
\$\end{array}$} & Coefficient & & & 0.518333 & & & 0.181262 \\
\hline & t-Statistic & & & 35.46235 & & & 19.44221 \\
\hline & Prob. & & & 0 & & & 0 \\
\hline \multirow[t]{3}{*}{ PS*FDI_\$ } & Coefficient & & & 0.184607 & & & -0.138261 \\
\hline & t-Statistic & & & 30.44782 & & & -9.095788 \\
\hline & Prob. & & & 0 & & & 0 \\
\hline \multirow[t]{3}{*}{ RQ*FDI_\$ } & Coefficient & & & -0.596239 & & & 0.166517 \\
\hline & $\mathrm{t}$-Statistic & & & -31.2504 & & & 28.40756 \\
\hline & Prob. & & & 0 & & & 0 \\
\hline \multirow{3}{*}{$\begin{array}{l}\text { RULE_OF_LA } \\
\text { W } \\
* \text { FDI_\$ }\end{array}$} & Coefficient & & & 0.133007 & & & 0.250488 \\
\hline & t-Statistic & & & 14.60586 & & & 27.96049 \\
\hline & Prob. & & & 0 & & & 0 \\
\hline \multirow{3}{*}{$\begin{array}{l}\text { V_AND_A*FD } \\
\text { I_\$ }\end{array}$} & Coefficient & & & -0.144232 & & & -0.502869 \\
\hline & t-Statistic & & & -12.30664 & & & -64.20189 \\
\hline & Prob. & & & 0 & & & 0 \\
\hline
\end{tabular}


In model 1 , there is a significant association between all independent variables and profit repatriation. But Inflation and GDP per Capital is positively significant and foreign direct investment is negatively and significantly affecting profit repatriation.

As we run model 2 with governance factors (Institutions Index), Profit Repatriation is our dependent variable and Inflation, GDP per Capital; Foreign Direct Investment and governance factors (Institutional Index) is our independent variables. Results suggested significant association between all independent variables and profit repatriation. Inflation, GDP, Control of Corruption, Government Effectiveness, and Regulatory Quality, Rule of law and Voice and Accountability were positively significant. Whereas foreign direct investment and Political stability is negatively and significantly affecting profit repatriation.

In model 3, we also included interaction effect of governance factors and foreign direct investment. Due to interaction affect all six factors of institutions are individually multiplied by foreign direct investment so we can see the impact of foreign direct investment and institutions quality on profit repatriation collectively. Results suggested a significant association between all independent variables (apart of Political Stability, Regulatory Quality, and Voice and Accountability) and profit repatriation. Interaction effect of Government Effectiveness, Political Stability, and Rule of law, each with FDI in predicting profit repatriation is positive and significant, whereas Regulatory Quality Voice and Accountability Control of Corruption have negative complementarities.

In model 1, all independent variables have a significant effect on Net Primary Income. All except Inflation and GDP per Capital have positive effect in Net Primary Income.

In model 2, governance factors were included. Apart from Control of Corruption, Political Stability, and Government Effectiveness, all other variables have a significant effect on Net Primary Income. Inflation, GDP, and most of the institutions inversely affect Net Primary Income.

Model 3, included interaction effect. As displayed, most of the institutions remain insignificant in affecting Net Primary Income, but with interaction, this affect turned significant. Voice and Accountability, Control of Corruption, Political Stability have negative complementarities whereas Government Effectiveness, Regulatory Quality, and Rule of law each have positive complementarities in FDI and Net Primary Income relationship

\section{Discussions}

So for our first model based on 54 developing countries, result reveals that as institutions are weak of developing countries and as they are negatively correlated with profit repatriation, means investors are unwilling to invest in countries where institutions encourage corruption, nepotism and red tape because these factors increase the cost of doing business (Mengistu and Adhikary 2011). Harms and Ursprung (2002) find that foreign investors invest in countries with strong democratic structures, while autocratic societies often experience policy reversal. Findings reveal that investors are interested in by taking their profit back to their own countries rather than to invest more in that country. Poor institutions attract less foreign direct investment and they make investors to feel that their investment is now no more 
profitable in a particular nation.

For our second model based on 100 countries (developing and developed both), as profit repatriation data is not available for developed countries so we have taken net primary income as a proxy of profit repatriation. Foreign direct investment impacted significantly with net primary income. But institutions factors have a negative impact on net primary income. As we have taken net primary income as a proxy of profit repatriation.

When we have run the 1st model (for 54 developing countries) without institutions keeping inflation, GDP per Capital and Foreign Direct Investment as independent variables, we find out all variables are significantly affecting Profit repatriation but Inflation and GDP per Capital are positively significant and foreign direct investment is negatively significant. As foreign direct investment and profit repatriation has a negative relation as discussed in previous studies. Foreign direct investment brings advanced technology and investment enhancing in the developing countries and when the foreign investment or profit on investment is repatriated this means that level of foreign direct investment is reduces in that particular country. When we have run the 1st model (for 46 developed countries) without institutions keeping inflation, GDP per Capital and Foreign Direct Investment as independent variables, we find out all variables are significantly impacting Net Primary Income (taken as a proxy of profit Repatriation) except inflation and GDP per capital which are negatively significant. There is a huge flow of foreign direct investment in developed countries and repatriation ratio is lower among developed countries. As developed countries are well equipped with their labor, technology and political stability, investors are re-investing their profit to take out maximum gain on their investment.

For our 2nd model (for 54 developing countries) with institutions keeping inflation, GDP per Capital, Institutional Index and Foreign Direct Investment as independent variables, we find out all variables are significantly affecting profit repatriation but only foreign direct investment and political stability are negatively significant as the political situations of majority of developing countries are not in a stable condition. Developing countries make policies to attract foreign direct investment because foreign firms brings technological advancement so they also have to provide them secure business environment so they can feel safe regarding their investment. Investor have to think thousand times now a days to invest in developing countries because of their worst situation.

For our 2nd model (for 46 developed countries) with institutions keeping inflation, GDP per Capital, Institutional Index and Foreign Direct Investment as independent variables, we find out Control of Corruption and Government Effectiveness has insignificant impact on net Primary Income as corruption is also exist in developed countries with a much higher ratio as compare to developing countries. All 46 countries have not same level of governance index. Some countries have high level of corruption and lack in government effectiveness. Foreign direct investment has a positive relation as investors does not think to repatriate their profit or investment as they feel secure with the environment provide by developed countries. With high level of corruption and lack of government effectiveness developed countries still managed to restrict the repatriation of profit because of their economic stability. 
Due to interaction affect all six factors of institutions are individually multiplied by foreign direct investment so we can see the impact of foreign direct investment and institutions quality on profit repatriation collectively. The presence of interaction effect in any research is important because it tells researchers how two or more variables are working together to impact the dependent variable. For our 3nd model (for 54 developing countries) has an interaction effect between institutions and foreign direct investment and keeping inflation, GDP per Capital, Institutional Index, and Foreign Direct Investment as independent variables. Interaction effect of Regulatory Quality, Voice and Accountability and Control of Corruption each with FDI in predicting profit repatriation is negative and significant. Foreign firms show reluctant to invest in developing countries as they have many issues including tax policies, unsafe environment, huge amount of corruption with no accountability, unstable political environment etc. The results are showing exactly the same approach as foreign direct investment has a negative relation with profit repatriation due to unsecure environment lack of regulatory quality, high level of corruption with no accountability and economic instability make investors to repatriate their investment back to their home country. For our 3nd model (for 46 developed countries) has an interaction effect between institutions and foreign direct investment and keeping inflation, GDP per Capital, Institutional Index, and Foreign Direct Investment as independent variables. Interaction effect of Voice and Accountability, Control of Corruption, Political Stability each with FDI in predicting net primary income have negative complementarities. As developed countries attracts foreign direct investment more than developing countries because of their safe and secure business healthy environment but they cannot hide the fact that huge level of corruption also exists in developed countries which has some kind of accountability and which also restrict foreign direct investment in some developed countries. But overall investors want to invest in developed countries rather than developing countries as they can make higher amount of profit by re-investing their profit again and again in the business secure investment.

\section{Conclusion}

Poor institutions attract less foreign direct investment and they make investors to feel that their investment is now no more profitable in a particular nation. Findings reveal that investors are interested in by taking their profit back to their own countries rather than to invest more in that particular country. We have also divided 54 developing and 46 developed countries in to 4 regions (European, Asian, African, and American) as well as in to low value institutions and high value institutions country wise. Scatter graph has elaborated their position regional wise. It is important to know the impact of foreign direct investment and institutions on profit repatriation in countries (regional wise).

The findings of this research are some countries with low value institutions attract foreign direct investment but they also do not have a control on repatriation of profits, as they do not have stable political and economic system. And remaining countries can't attract foreign direct investment as they do not have secure business environment or strong rule of law. Countries with high value institutions really attract foreign firms as they have a business friendly environment, tax efficient system and stable political and economic system for foreign direct investment. This research will provide a huge scope for upcoming researchers 
about profit repatriation and its implications in the modern world. The relationship of foreign direct investment and profit repatriation is of great significance as they shows how much countries are currently attracting foreign firms to re-invest their profit in that particular country and how much countries are attracting foreign direct investment which is hugely depending on the quality of their institutions.

Significance of this research is huge, as this type of research hasn't been done before. The gap that has been found in many of the past researches is that profit repatriation has not been use as a dependent variable; it has always been use as an independent variable. First time profit repatriation is being use as a dependent variable which has its own significance. Profit repatriation is really important for host nation as well as for the foreign country as well. Foreign direct investment encourages employment growth, flow of cash in economy, technological advancement and if institutions of a country are not strong enough to attract foreign firms to do huge investment so those who have already investment thinks about to secure their invested money by taking their money to home country. If a host nation do not provide a business environment to foreign firms which include tax efficient system, business friendly environment, good control on corruption, strong rule of law, strong accountability system, stable political and economic situation then they can't attract foreign direct investment in their country.

\section{References}

Arellano, M., \& Bover, O. (1995). Another look at the instrumental variable estimation of error-components models. Journal of econometrics, 68(1), 29-51.

https://doi.org/10.1016/0304-4076(94)01642-D

Blundell, R., \& Bond, S. (1998). Initial conditions and moment restrictions in dynamic panel data models. Journal of econometrics, 87(1), 115-143.

https://doi.org/10.1016/S0304-4076(98)00009-8

Buchanan, B. G., Le, Q. V., \& Rishi, M. (2012). Foreign direct investment and institutional quality: Some empirical evidence. International Review of financial analysis, 21, 81-89. https://doi.org/10.1016/j.irfa.2011.10.001

Dang, D. A. (2013). How foreign direct investment promote institutional quality: Evidence from Vietnam. Journal of Comparative Economics, 41(4), 1054-1072.

https://doi.org/10.1016/j.jce.2013.05.010

Daude, C., \& Stein, E. (2007). The quality of institutions and foreign direct investment. Economics \& Politics, 19(3), 317-344. https://doi.org/10.1111/j.1468-0343.2007.00318.x

Du, J., Lu, Y., \& Tao, Z. (2008). Economic institutions and FDI location choice: Evidence from US multinationals in China. Journal of comparative Economics, 36(3), 412-429. https://doi.org/10.1016/j.jce.2008.04.004

Foreign direct investment, net (BoP, current US\$) | Data. (n.d.). [Online] Available: https://data.worldbank.org/indicator/BN.KLT.DINV.CD 
GDP per capita growth (annual \%) | Data. (n.d.). [Online] Available:

https://data.worldbank.org/indicator/NY.GDP.PCAP.KD.ZG

Harms, P., \& Ursprung, H. W. (2002). Do civil and political repression really boost foreign direct investments?. Economic inquiry, 40(4), 651-663. https://doi.org/10.1093/ei/40.4.651

Hussain, F., \& Kimuli, C. K. (2012). Determinants of foreign direct investment flows to developing countries. SBP Research Bulletin, 8(1), 13-31.

Inflation, GDP deflator: linked series (annual \%) | Data. (n.d.). [Online] Available:

https://data.worldbank.org/indicator/NY.GDP.DEFL.KD.ZG.AD

Jude, C., \& Levieuge, G. (2015). Growth effect of FDI in developing economies: the role of institutional quality. https://doi.org/10.2139/ssrn.2620698

Lehman, A. (2002). FDI in Emerging Markets: Income, repatriations and Financial vulnerabilities. IMF working paper 02/47, Whashington DC.

https://doi.org/10.5089/9781451846652.001

Mengistu, A. A., \& Adhikary, B. K. (2011). Does good governance matter for FDI inflows? Evidence from Asian economies. Asia Pacific business review, 17(3), 281-299.

https://doi.org/10.1080/13602381003755765

Net primary income (BoP, current US\$) | Data. (n.d.). [Online] Available:

https://data.worldbank.org/indicator/BN.GSR.FCTY.CD

Development Co-operation Report 2012 - OECD. (n.d.). [Online] Available:

https://www.oecd.org/development/dcr2012.htm

Peres, M., Ameer, W., \& Xu, H. (2018). The impact of institutional quality on foreign direct investment inflows: evidence for developed and developing countries. Economic research-Ekonomska istraživanja, 31(1), 626-644.

https://doi.org/10.1080/1331677X.2018.1438906

Data | The World Bank. (n.d.). [Online] Available:

https://data.worldbank.org/indicator/BX.KLT.DREM.CD.DT?end=2015\&locations=

Sabir, S., Rafique, A., \& Abbas, K. (2019). Institutions and FDI: evidence from developed and developing countries. Financial Innovation, 5(1), 8.

https://doi.org/10.1186/s40854-019-0123-7

Sanderatne, N. (2013). Livelihoods and Poverty in Sri Lanka.

Trojette, I. (2016). The effect of foreign direct investment on economic growth: The institutional threshold. Région et Développement, 43, 112-138.

UNCTAD ANNUAL REPORT 2002. (n.d.). [Online] Available:

https://unctad.org/en/Docs/edm20033_en.pdf

Worldwide Governance Indicators (WGI) | Data Catalog. (n.d.). [Online] Available:

https://datacatalog.worldbank.org/dataset/worldwide-governance-indicators 


\section{Copyright Disclaimer}

Copyright for this article is retained by the author(s), with first publication rights granted to the journal.

This is an open-access article distributed under the terms and conditions of the Creative Commons Attribution license (http://creativecommons.org/licenses/by/4.0/). 